\title{
Citrus pulp-based supplement reduces the detrimental effects of high grazing pressure on the performance of beef cattle under a rotational system of Urochloa brizantha
}

\author{
Suplemento energético a base de polpa cítrica diminui os efeitos deletérios da alta \\ pressão de pastejo no desempenho de bovinos de corte em sistema rotacionado de \\ Urochloa brizantha
}

\begin{abstract}
Costa, Diogo Fleury Azevedo ${ }^{1,2, *}$; Da Silva, Sila Carneiro ${ }^{1}$; Bittar, Carla Maris ${ }^{1}$; Takiya, Caio Seiti $^{3,4}$; Dórea, João Ricardo Reboucas ${ }^{1,5}$; Del Valle, Tiago Antonio ${ }^{3}$; Malafaia, Pedro ${ }^{6}$; Santos, Flavio Augusto Portela ${ }^{1}$
\end{abstract}

\begin{abstract}
${ }^{1}$ Department of Animal Sciences, College of Agriculture "Luiz de Queiroz", University of Sao Paulo, Piracicaba, SP 13418900 Brazil

${ }^{2}$ Centre for Animal Science, Queensland Alliance for Agriculture and Food Innovation, Gatton, QLD, 4343 Australia

${ }^{3}$ Department of Nutrition and Animal Production, University of Sao Paulo, Pirassununga, SP 13635-900 Brazil

${ }^{4}$ Department of Animal Sciences and Industry, Kansas State University, Manhattan, KS 66506 USA

${ }^{5}$ College of Agriculture and Life Sciences, University of Wisconsin, Madison, WI 53715 USA

${ }^{6}$ Federal Rural University of Rio de Janeiro, Department of Animal Nutrition and Pastures, Seropedica, RJ, Brazil 23897000;

*Corresponding author: Diogo Costa, e-mail: d.costa@uq.edu.au, phone: +61409445454

Queensland Alliance for Agriculture and Food Innovation, Gatton, QLD, Australia 4343.

ORCID ID

https://orcid.org/0000-0001-8118-8380
\end{abstract}

\section{SUMMARY}

The objectives were to evaluate the performance of bull calves under two grazing strategies and the use of energy supplementation in a rotational system of marandu palisade grass (Urochloa brizantha) and to assess the morphological and chemical composition of the grass. Eighty eightmonth-old bulls of $224 \pm 2.4 \mathrm{~kg}$ body weight (BW) were used in a completely randomized block design in a $2 \times 2$ factorial arrangement of two post-grazing heights (i.e. $10 \mathrm{~cm}$ or $15 \mathrm{~cm}$ )and of a citrus pulp-based supplement (i.e.72\% total digestible nutrients) fed daily at 0 or $6 \mathrm{~g} / \mathrm{kg} \mathrm{BW}$. Initial grazing height was set at $25 \mathrm{~cm}$ with variable grazing intervals and stocking rate adjustments used to control the grazing heights. Statistical analyses were performed using the SAS Mixed procedure. Significance was set at 0.05 . Forage data from 12 pre-determined paddocks showed no differences in forage mass (FM)and morphological composition at pre-grazing, but greater post-grazing FM and shorter grazing interval in pastures managed at $15 \mathrm{~cm}$. Higher grazing pressure resulted in lowest BW gains for non-supplemented bulls in the $10 \mathrm{~cm}$ treatment. The use of an energy supplement and $15 \mathrm{~cm}$ postgrazing height resulted in the greatest BW gains; however, combination of $10 \mathrm{~cm}$ post-grazing height and energy supplementation allowed greater stocking rates. Under high grazing pressure, supplementary feed overcame the normal limitations, and high gains were achieved.

Keywords: Energy supplementation, grazing management, tropical pasture.

\section{RESUMO}

Os objetivos foram avaliar o desempenho de tourinhos em duas estratégias de pastejo e a suplementação energética em um sistema de 
lotação rotacionadade capim marandu (Urochloa brizantha) e avaliar a composição morfológica e bromatológica da gramínea. Oitenta bezerros não castrados com 8 meses de idade $[224 \pm 2,4 \mathrm{~kg}$ peso vivo (PV)] distribuídos em blocos casualizados com arranjo fatorial $2 \times 2$ entre altura de saída (i.e. $10 \mathrm{~cm}$ ou $15 \mathrm{~cm}$ ) e suplemento (i.e.72\% nutrientes digestíveis totais) fornecido diariamente à0 ou $6 \mathrm{~g} / \mathrm{kg}$ PV. Análises estatísticas foram feitas com o procedimento Mixed do SAS, adotando-se nível de significância à 0,05 . A altura de entrada nos pastos foi de $25 \mathrm{~cm}$. O intervalo entre pastejos foi variável com taxa de lotação ajustada de acordo com as premissas de pastejo. A massa de forragem (MF) pré- e pós-pastejo, taxa de crescimento da MF e o acúmulo de MF foram mensuradas em 12 piquetes pré-determinados. A
MF no pré-pastejo foi semelhante, porém maior MF e menor intervalo entre pastejos foram observados nos pastos com altura de saída de 15 $\mathrm{cm}$. A composição morfológica entre os dois manejos foi semelhante na entrada, porém a proporção de folhas foi maior no $15 \mathrm{~cm}$. A suplementação combinada a altura de saída de 15 $\mathrm{cm}$ gerou os maiores ganhos. Porém, a suplementação associada a altura de saída de 10 cm permitiu maior taxa de lotação,não afetando produtividade. Os efeitos deletérios da pressão de pastejo sobre o desempenho animal foram reduzidos quando a suplementação foi utilizada.

Palavras-chave: Manejo do pastejo, pastagem tropical, suplementação energética. 


\section{INTRODUCTION}

In a scenario where world population is increasing under uncertain climatic conditions, combined efforts should be sought to increase farming efficiency and food production per area. The main factors affecting nutrient intake by grazing ruminants, which would directly affect their performance, are forage allowance (Drescher et al., 2006) and sward structure (da Silva et al., 2013); both affected by grazing pressure, defined as the ratio of the animal bodyweight (BW) to forage mass per area. Hodgson (1990) indicated that's wards managed at95\% light interception (LI) at the initial grazing point resulted in pastures with greater forage yield, with increased proportion of leaves and decreased proportion of stems. The adopted sward height of $25 \mathrm{~cm}$ in this work is correlated to $95 \% \mathrm{LI}$ on pastures of marandu palisade grass(Urochloa brizantha), regardless of the post-grazing height (Trindade et al., 2007).In spite of this, the grazing pressure used to reduce the post-grazing height may affect animal performance, considering that forage mass (FM) ingestion rate of grams of dry matter (DM) per minutes depressed when cattle are forced to graze down more than $40 \%$ of the initial sward height (Fonseca et al., 2012).Energy supplementation for cattle grazing tropical pastures under a high stocking rate could potentially minimize these deleterious effects by increasing energy intake, there by leading to improvements in performance. Santos et al. (2014) reportedthat feeding a corn-based energy supplement at6 $\mathrm{g} \mathrm{DM} / \mathrm{kg} \mathrm{BW}$ to grazing yearling bulls decreased forage intake by $18.4 \%$, but increased total DM intake by $10.5 \%$. Hence, the use of citrus pulp in the current experiment, a feedstuff high in pectin, used as the energy supplement at $6 \mathrm{~g} \mathrm{DM} / \mathrm{kg} \mathrm{BW}$, as recommended by Santos and colleagues (2014).
The primary objective of this study was to evaluate the performance of bull calves under two grazing intensities in a rotational grazing system of marandu palisade grass in combination with energy supplementation. Secondly, the morphological characteristics and chemical composition of the grass were evaluated. We hypothesized that feeding an energy supplement to weaner grazing cattle would reduce the detrimental effects of high grazing pressure on animal performance, thereby increasing beef yield in the system.

\section{MATERIAL AND METHODS}

All procedures were conducted in accordance with the guidelines of the Animal Care and Use Committee of the College of Agriculture "Luiz de Queiroz", University of Sao Paulo (ESALQ-USP).

\section{Experimental area and preliminary procedures}

The experiment was conducted at the Animal Sciences Department of the ESALQ-USP, Piracicaba, SP, Brazil. The experimental area was 8.5 ha uniformly covered with marandu palisade grass (Urochloa brizantha, syn. Brachiaria brizantha), and divided into four sub-areas containing eight paddocks each. Thus, there were 32 paddocks, of 0.265 ha each. Cattle had access to management centers equipped with feed bunks and water troughs in each sub-area.

The experimental period lasted 180 days from November2005 to May2006. Pasture data was collected throughout the experiment, but only the first 105 days were considered in the analyses because climate conditions did not allow the pastures to fully recover and reach sward heights of $25 \mathrm{~cm}$ during the final experimental period. The maximum and minimum temperatures during the whole 
experiment were 28.8 and $16.9{ }^{\circ} \mathrm{C}$, respectively, with $607 \mathrm{~mm}$ of rain. For 114 days prior to the start of the trial, pastures were managed using Nellore cows from the department's breeding herd. Grazing intervals were variable and stocking rate adjustments with different occupation periods were used to control the grazing heights. About $75 \mathrm{~kg} \mathrm{~K} / \mathrm{ha}, 36 \mathrm{~kg}$ P/ha and $30 \mathrm{~kg}$ micronutrients mixture/ha were applied on October 2005, and then, approximately $2.5 \mathrm{~kg} \quad \mathrm{~N} / \mathrm{ha} /$ day was applied in the form of urea, between grazing cycles.

\section{Animals and treatments}

Eighty crossbred ( $1 / 4$ St. Gertrudis $\times 1 / 4$ Nellore $\times 1 / 2$ Brown Swiss) bull calves, 8 months of age and $224 \pm 2.4 \mathrm{~kg}$ BW (mean \pm SEM), were used. A second cohort of 70 animals was used to adjust the stocking rate. Two groups consisting of supplemented and non-supplemented bull calves were rotated between the two subareas managed with $10 \mathrm{~cm}$ of post-grazing height, whilst the other two groups rotated between the sub-areas managed with 15 $\mathrm{cm}$ of post-grazing height. If not in the experimental area, the cohort animals were kept in an area with the same management regime. Cattle were vaccinated for foot and mouth disease, clostridiums, and rabies, with Bovicel (Valée, Montes Claros, Brazil), Fortress 7, and Rai-Vac K (Zoetis, Campinas, Brazil), respectively, and treated for internal and external parasites every 60 days with either Dectomax $(1 \%$ w/v Doramectin, Zoetis) or Ivomec (1\% w/v Ivermectin, Merial, Campinas, Brazil).Animals were blocked by initial BW and randomly allocated to one of four treatments:1) no supplement and $10 \mathrm{~cm}$ post-grazing height,2)no supplement and $15 \mathrm{~cm}$ post-grazing height,3) $6 \mathrm{~g}$ of supplement $\mathrm{kg} \mathrm{BW/day} \mathrm{(on} \mathrm{DM-basis)} \mathrm{and}$ $10 \mathrm{~cm}$ of post-grazing height, and 4)6 $\mathrm{g}$ of supplement kg BW/day (on DM-basis)and
$15 \mathrm{~cm}$ of post-grazing height. The supplement $(905 \mathrm{~g} / \mathrm{kg}$ of DM, $110 \mathrm{~g} / \mathrm{kg} \mathrm{CP}$, and $720 \mathrm{~g} / \mathrm{kg}$ of total digestible nutrients) consisted of $803 \mathrm{~g} / \mathrm{kg}$ citrus pulp, $154 \mathrm{~g} / \mathrm{kg}$ cottonseed meal, $43 \mathrm{~g} / \mathrm{kg}$ minerals, and 90 ppm of sodium monensin on a DM basis, which was offered each day, fed as a group. Adjustments on total amount of supplement offered were done after each weighing interval.

\section{Pasture management and forage collection}

The grazing height utilized as the starting point in the current work was chosen based on the high correlation found in marandu palisade grass by Trindade et al. (2007) with $95 \% \mathrm{LI}$, which is considered as the ideal point to maximize forage yield with increased the proportion of leaves and decreased proportion of stems (Hodgson, 1990). The pre-grazing sward grazing height of $25 \mathrm{~cm}$ was achieved by varying the stocking rate, occupation periods, and grazing intervals throughout the experiment. Allocation of animals within paddocks was based on the estimated amount of FM present in the paddock and the amount necessary to be removed to achieve the aimed post-grazing height, by estimating the period until the next paddock reached $25 \mathrm{~cm}$. The sward height was measured (Fagundes et al., 1999) in all paddocks at every grazing cycle. Pre-and post-grazing FM, forage growth rate (FGR), and the accumulated FM were measured in 12 pre-determined paddocks $(6$ for each pasture management regime)using 4 samples per collection, cut at $1 \mathrm{~cm}$ above ground level with the use of a rectangular frame of $0.5 \mathrm{~m}^{2}$. Forage accumulation $(\mathrm{kg}$ DM ha/day) was calculated from FM differences in pre- and post-grazing in every grazing cycle for 105 days. The FM accumulated in every grazing cycle was used to calculate FGR. Total FM accumulated was calculated from FGR and 
extrapolated to 105 days because of different grazing intervals between treatments. Morphological composition was determined using DM proportions of leaf, stem, and dead material from a subsample of approximately 500g.The leaf component was considered as the leaves that had completely emerged from the sheath. Dead material was considered as any leaf or stem with $50 \%$ or more of the superficial area and a yellowish color. Grazing horizon FM samples were collected from all paddocks. Briefly, four different areas within the paddocks were delimited by square metal frames $\left(0.25 \mathrm{~m}^{2}\right)$ and forage was cut above the post-grazing heights of 10 or $15 \mathrm{~cm}$. Samples from each paddock were analyzed for chemical composition. Approximately 500g from each of the latter samples was oven dried at $55{ }^{\circ} \mathrm{C}$ for $72 \mathrm{~h}$, and ground through a 1 $\mathrm{mm}$ screen. Moisture and organic matter content were determined according to AOAC (1990) methods. Nitrogen was determined using Leco FP-2000 (Leco Instruments, Inc. St. Joseph, MI) and a conversion factor of 6.25 forCP estimates. Ash-free neutral detergent fiber (NDF) and ash-free acid detergent fiber (ADF) were determined according to Van Soeste $t$ al.(1991) using ANKON bags (ANKON Technology Fairport, New York). Total ether extract was determined according to AOAC(1990) and in vitro degradability of organic matter (IVOMD) and DM (IVDMD) according to Goering and Van Soest (1970).

The experimental animals were used as markers and, if necessary, a non-fixed number of animals were used to control sward heights according to treatment. The FM of the grazing horizon collected from each paddock before grazing was initiated, was used to calculate FM allowance and allocate animals in paddocks. Based on observations obtained prior to the start of the experiment, FM allowance required for a lower grazing pressure was $0.4 \mathrm{~g} / \mathrm{kg} \mathrm{BW}$, whereas $0.25 \mathrm{~g} / \mathrm{kg} \mathrm{BW}$ was used for the higher grazing pressure, discounting the extra DM supplied as feed for the supplemented animals.

\section{Animal performance}

Animals were weighed at the start of the experiment and every 30 days after a 14 hour curfew of feed and water. Individual average daily gain (ADG) was calculated as the slope of the BW as a function of the time, and it was expressed in $\mathrm{kg} / \mathrm{d}$. Stocking rate and beef yield were calculated using the sum of the BW averages and the ADG data of the animals used as markers, respectively.

\section{Statistical analysis}

Data of pasture productivity, morphological, and chemical composition were analyzed using the MIXED procedure of SAS (version 9.4, SAS Institute, Cary, NC), according to the model below:

$$
Y_{i j k l}=\mu+P M_{i}+\omega_{j: i}+C_{k}+e_{i j k}
$$

In which: $\quad \omega_{\mathrm{i}: \mathrm{j}} \approx \mathrm{N}\left(0, \sigma_{\omega}^{2}\right) \quad$ and $\mathrm{e}_{\mathrm{ijk}} \approx \operatorname{MVN}(0, \mathrm{R})$; where, $\mathrm{Y}_{\mathrm{ijk} \mathrm{l}}$ is the value of dependent variable; $\mu$ is the overall mean; $\mathrm{PM}_{\mathrm{i}}$ is the fixed effect of pasture management ( $\mathrm{i}=1$ and 2$) ; \omega_{\mathrm{i}: \mathrm{i}}$ is the random effect of paddock $j$ within $i^{\text {th }}$ level of pasture management $(\mathrm{j}=1$ to 12$) ; \mathrm{C}_{\mathrm{k}}$ is the fixed effect of pasture cycle $(\mathrm{k}=1$ to 5); $\mathrm{e}_{\mathrm{ijk} \mathrm{l}}$ is the residual error; $\mathrm{N}$ stands for the Gaussian distribution; $\sigma_{\omega}^{2}$ is the variance associated with paddocks; MVN stands for the multivariate normal; and $\mathrm{R}$ is the variance-covariance matrix of residuals due to the repeated measurements. Autoregressive (AR) matrix was applied for all variables. Degrees of freedom were calculated according to Kenward and Rogers (1997). The least square means and SEM values for each pasture management are presented. Data of animal performance 
were analyzed using the MIXED procedure

of SAS, and the following model:

$$
Y_{i j k}=\mu+P M_{i}+S_{j}+P M \times S_{i j}+b_{k}+e_{i j k}
$$

In which: $\mathrm{b}_{\mathrm{k}} \approx \mathrm{N}\left(0, \sigma_{\mathrm{b}}^{2}\right)$ and $\mathrm{e}_{\mathrm{ijk}} \approx \mathrm{N}(0$, $\left.\sigma_{\mathrm{e}}^{2}\right)$; where, $\mathrm{Y}_{\mathrm{ijk}}$ is the value of dependent variable; $\mu$ is the overall mean; $\mathrm{PM}_{\mathrm{i}}$ is the fixed effect of pasture management ( $\mathrm{i}=1$ and 2 ); $\mathrm{S}_{\mathrm{j}}$ is the fixed effect of animal supplementation $\left(\mathrm{j}=1\right.$ and 2); $P M \times S_{i j}$ is an interaction term; $b_{k}$ is the random effect of block $(k$ $=1$ to 20); $\mathrm{e}_{\mathrm{ijk}}$ is experimental error; $\mathrm{N}$ stands for the Gaussian distribution; $\sigma_{\mathrm{b}}^{2}$ and $\sigma_{\mathrm{e}}^{2}$ are variances associated with blocks and residual, respectively. As we had a balanced trial, we showed a general residual SEM for each variable. Because animals were maintained in different paddocks in each interval between BW measurements for the 30 days of evaluation period, the experimental group (supplementation and pasture management combination) within each period was considered the experimental unit for stocking rate (AU/ha) and beef yield ( $\mathrm{kg} / \mathrm{ha} /$ day) evaluations. In this approach, the limitations are recognized, but it was decided to allow a discussion based on statistical significance. A similar model to the one used for animal performance evaluation was applied to evaluate stocking rate and beef yield, replacing the random effect of blocks with the random effect of evaluation period $(k=$ 1 to 5 ).

\section{RESULTS}

Productivity, morphology, and chemical composition of pastures

The initial grazing sward height maintained for both treatments did not vary $(\mathrm{P}=0.224)$, resulting in similar FM $(\mathrm{P}=0.671)$ between treatments. In contrast, post-grazing FM was lower $(\mathrm{P}=0.004)$ for the treatment of $10 \mathrm{cms}$ ward height at post-grazing. As planned, post-grazing sward height was lower $(\mathrm{P}<0.001)$ in pastures managed with $10 \mathrm{~cm}$ compared to those managed with $15 \mathrm{~cm}$ at post-grazing. Forage accumulation, forage growth rate, and bulk density were similar $(\mathrm{P}>0.05)$ between treatments. The average grazing interval for pastures managed at $10 \mathrm{~cm}$ was higher $(\mathrm{P}=0.006)$ than those managed with $15 \mathrm{~cm}$ of height at postgrazing

(Table

1). 
Table 1. Pre- and post-grazing sward heights, forage mass (FM), bulk density, total forage accumulation, growth rate, and grazing interval of marandu palisade grass (Uruchloa brizantha) subjected to different grazing intensities

\begin{tabular}{llll}
\hline \multirow{2}{*}{ Item } & \multicolumn{2}{l}{ Post-grazing sward height } & \multirow{2}{*}{ P-value } \\
\cline { 2 - 3 } & $10 \mathrm{~cm}$ & $15 \mathrm{~cm}$ & \\
\hline Pre-grazing sward height $(\mathrm{cm})$ & $24.5 \pm 0.47$ & $25.1 \pm 0.42$ & 0.224 \\
Post-grazing sward height (cm) & $11.5 \pm 0.29$ & $15.3 \pm 0.24$ & $<0.001$ \\
Pre-grazing FM (kg DM/ha) & $4914 \pm 234.4$ & $5019 \pm 209.6$ & 0.671 \\
Post-grazing FM (kg DM/ha) & $2695 \pm 163.2$ & $3254 \pm 131.9$ & 0.004 \\
Bulk density (kg DM/ha/cm) & $144 \pm 13.5$ & $117 \pm 12.4$ & 0.051 \\
Forage accumulation (kg DM/ha/cycle) & $2230 \pm 272.8$ & $1704 \pm 212.7$ & 0.076 \\
Total forage accumulation ${ }^{1}(\mathrm{~kg} \mathrm{DM} / \mathrm{ha})$ & $9996 \pm 2395$ & $9881 \pm 1537$ & 0.969 \\
Forage growth rate (FGR) $(\mathrm{kg} \mathrm{DM} \mathrm{ha/day)}$ & $95.2 \pm 21.5$ & $94.1 \pm 17.0$ & 0.962 \\
Grazing interval (days) & $23.9 \pm 1.73$ & $18.2 \pm 1.35$ & 0.006 \\
\hline
\end{tabular}

${ }^{1}$ Total FM accumulated was calculated from FGR of sampling paddocks and extrapolated to105 days.

Pasture morphological composition at pre-grazing was similar $(\mathrm{P} \geq 0.407)$ between pastures. However, the $10 \mathrm{~cm}$ post-grazing treatment had a lower proportion of leaf $(\mathrm{P}=0.001)$ and a greater proportion of dead material $(\mathrm{P}=0.001)$ compared to those managed at $15 \mathrm{~cm}$ post-grazing(Table 2 ).

Table 2. Morphological composition of marandu palisade grass under two grazing intensities

\begin{tabular}{lccc}
\hline \multirow{2}{*}{ Item } & \multicolumn{2}{l}{ Post-grazing sward height } & \multirow{2}{*}{ P-value } \\
\cline { 2 - 3 } & $10 \mathrm{~cm}$ & $15 \mathrm{~cm}$ & \\
\hline Pre-grazing $(\mathrm{g} / \mathrm{kg} \mathrm{DM})$ & $536 \pm 41.0$ & $514 \pm 36.8$ & 0.604 \\
Leaf & $353 \pm 24.5$ & $348 \pm 22.5$ & 0.854 \\
Stem & $111 \pm 26.8$ & $135 \pm 23.9$ & 0.407 \\
Dead material & & & \\
Post-grazing (g/kg DM) & $199 \pm 25.7$ & $295 \pm 21.1$ & 0.001 \\
Leaf & $472 \pm 25.9$ & $456 \pm 21.2$ & 0.547 \\
Stem & $326 \pm 22.9$ & $248 \pm 19.2$ & 0.001 \\
Dead material & & & \\
\hline
\end{tabular}

As expected, pastures (i.e .grazing horizon samples) had a similar chemical composition, with the exception that lignin content was greater $(\mathrm{P}=0.018)$ in pastures managed at $10 \mathrm{~cm}$ (Table 3 ).
No differences were detected $(\mathrm{P} \geq 0.299)$ on in vitro $\mathrm{DM}$ and organic matter degradability between pasture management regimes(Table 3 ). 
Table 3. Chemical composition of grazing horizon samples of marandupalisadegrass pastures under different grazing intensities

\begin{tabular}{llll}
\hline \multirow{2}{*}{ Item } & \multicolumn{2}{l}{ Post-grazing sward height } & \multirow{2}{*}{ P-value } \\
\cline { 2 - 3 } & $10 \mathrm{~cm}$ & $15 \mathrm{~cm}$ & \\
\hline Dry matter $(\mathrm{g} / \mathrm{kg}$ as fed $)$ & $194 \pm 10.0$ & $207 \pm 8.9$ & 0.249
\end{tabular}

Forage composition(g/kg DM)

Neutral detergent fiber

Acid detergent fiber

Hemicellulose

Cellulose

Lignin

Crude Protein

Ash

Non-fiber carbohydrate

Ether extract

In vitro degradability $(\mathrm{g} / \mathrm{kg})$

Dry matter

Organic matter
$611 \pm 6.0$

$617 \pm 5.4$

0.553

$\begin{array}{lll}631 \pm 14.5 & 616 \pm 12.4 & 0.413 \\ 313 \pm 6.2 & 309 \pm 5.1 & 0.532 \\ 319 \pm 11.9 & 309 \pm 10.2 & 0.500 \\ 278 \pm 6.8 & 284 \pm 5.6 & 0.441 \\ 34.2 \pm 3.64 & 25.4 \pm 3.02 & 0.018 \\ 154 \pm 5.9 & 157 \pm 4.7 & 0.675 \\ 107 \pm 0.89 & 101 \pm 0.73 & <0.001 \\ 81.8 \pm 18.8 & 99.0 \pm 15.6 & 0.440 \\ 22.6 \pm 0.30 & 22.5 \pm 0.26 & 0.577\end{array}$

$631 \pm 5.9 \quad 623 \pm 5.2$

0.299

\section{Animal performance}

Energy supplementation increased $(\mathrm{P} \leq 0.018) \quad \mathrm{ADG}$, final $\mathrm{BW}$, stocking rate, and beef yield (Table 4).Adopting a higher grazing pressure at $10 \mathrm{~cm}$ postgrazing reduced $(P<0.001)$ the ADG and final $\mathrm{BW}$, but increased $(P<0.001)$ stocking rate and had no effect on beef yield. No interaction effects between energy supplementation and pasture management were observed $(\mathrm{P} \geq 0.128)$ in the animal performance variables (Table 4). 
Table 4. Average daily gain (ADG), stocking rate (SR), beef yield (BY), and final body weight (BW) of bull calves supplemented or nonsupplemented under different grazing intensities

\begin{tabular}{|c|c|c|c|c|c|c|c|c|}
\hline \multirow{3}{*}{ Item } & \multicolumn{4}{|c|}{ Treatment $^{1}$} & \multirow{3}{*}{ SEM } & \multirow{2}{*}{\multicolumn{3}{|c|}{ P-value ${ }^{2}$}} \\
\hline & \multicolumn{2}{|c|}{ Post-grazing sward height of $10 \mathrm{~cm}$} & \multicolumn{2}{|c|}{ Post-grazing sward height of $15 \mathrm{~cm}$} & & & & \\
\hline & Non-supplemented & Supplemented & Non-supplemented & Supplemented & & SUP $^{2}$ & $\mathrm{GP}^{3}$ & SUP $\times$ GP \\
\hline Initial BW (kg) & 219 & 225 & 225 & 225 & 2.4 & 0.475 & 0.539 & 0.530 \\
\hline ADG (kg/d) & 0.397 & 0.790 & 0.519 & 0.907 & 0.0213 & $<0.001$ & 0.001 & 0.934 \\
\hline Final BW (kg) & 291 & 369 & 319 & 390 & 5.6 & $<0.001$ & $<0.001$ & 0.573 \\
\hline $\mathrm{SR}\left(\mathrm{AU}^{3} / \mathrm{ha}\right)$ & 7.04 & 8.45 & 5.77 & 6.12 & 0.276 & 0.018 & $<0.001$ & 0.128 \\
\hline BY (kg ha/d) & 5.70 & 11.3 & 5.62 & 9.08 & 0.833 & $<0.001$ & 0.121 & 0.146 \\
\hline
\end{tabular}

${ }^{\mathrm{l}}$ Different post-grazing sward heights and the use of a citrus pulp-based energy supplement fed daily at 0 or $6 \mathrm{~g} / \mathrm{kg}$ BW. ${ }^{2} \mathrm{Probabilities} \mathrm{for} \mathrm{effects}$ of supplement (SUP), grazing pressure (GP), and their interaction. ${ }^{3}$ Animal unit $=450 \mathrm{~kg} \mathrm{BW}$. 


\section{DISCUSSION}

The use of a citrus pulp-based supplement on a well-managed tropical pasture during the wet season increased the ADG of growing bulls. Energy intake was most likely the primary limiting factor for performance, considering that the $\mathrm{CP}$ content of grasses appeared adequate for growing cattle (NRC, 2000) in both grazing intensities. The quality of marandu palisade grass at the pre-grazing condition in combination with the supplement, provided not only the protein, but also supplied the metabolizable energy required for improvements in performance. The higher forage allowance in the $15 \mathrm{~cm}$ post-grazing height resulted in an intermediate ADG for nonsupplemented animals in that treatment, but the use of a supplement at $6 \mathrm{~g} / \mathrm{kg}$ BW decreased the deleterious effect of lower ADG observed in nonsupplemented animals in pastures managed at $10 \mathrm{~cm}$ post-grazing height. The net intestinal absorption of protein from tropical grasses is relatively low due to their low energy content, leading to $\mathrm{N}$ losses when $\mathrm{CP}$ exceeds either 210 $\mathrm{g}$ of $\mathrm{CP} / \mathrm{kg}$ of digestible organic matter or $151 \mathrm{~g}$ of $\mathrm{CP} / \mathrm{kg}$ DM (Poppi \& McLennan, 1995). In cases where the digestibility of grass is below $70 \%$, such as was observed in the current experiment, values of $\mathrm{CP}$ of $132 \mathrm{~g} / \mathrm{kg}$ of DM would be in excess and would lead to $\mathrm{N}$ losses. Thus, the energy supplementation may have increased the digestibility of the diet, considering that there were no differences between the in vitro digestibility of forage samples, allowing a more efficient utilization of the grazed forage. The $10 \mathrm{~cm}$ postgrazing height increased stocking ratebut decreased performance when supplementation was not in place.

The use of an adequate grazing height for pasture management (Hodgson, 1990; Congio et al., 2018) resulted in high FGR and FM accumulation and a high proportion of leaves in FM at pregrazing, independent of the grazing intensity. The $25 \mathrm{~cm}$ pre-grazing and $15 \mathrm{~cm}$ post-grazing heights were reached satisfactorily. However, the $10 \mathrm{~cm}$ postgrazing height was not reached consistently, averaging11.3 $\mathrm{cm}$. Similarly, in pastures of marandu palisade grass managed at $95 \%$ LI at pre-grazing, Trindade et al. (2007) could not reach lower post-grazing heights in more severe grazing, such as $10 \mathrm{~cm}$, during the higher growth season, averaging $12.7 \mathrm{~cm}$ over summer.

More severe grazing had no negative effects on pre-grazing FM and morphological composition in the current experiment but resulted in fewer leaves and more dead material in postgrazing FM of marandu palisade grass, similar to results reported by Trindade et al.(2007). The chemical composition of the grazing horizon FM in the current experiment was also similar between treatments. The leaf is most likely the main component influencing forage intake because of its relatively high digestibility (Poppi et al., 1981). High grazing intensity may reduce intake since there is a decrease in the proportion of green leaves, as observed in the current study, but it can potentially increase harvest efficiency (Carnevalli et al.,2006). Dairy cows grazing elephant grass (Pennisetum purpureum) managed at $95 \%$ LI were almost $10 \%$ more efficient on the harvesting process that resulted in an extra $2.0 \mathrm{~kg}$ of milk per day compared to cows grazing pastures managed at 
maximum LI (Congio et al., 2018).The grazing efficiency in the work of Carnevalli et al. (2006) using Mombaça grass (Panicum maximum) reached maximum efficiency (87\%) when a treatment of $95 \%$ LI was combined with more severe grazing (i.e. $30 \mathrm{~cm}$ vs 50 $\mathrm{cm})$. Stems impose a physical barrier to the grazing process and more intense grazing forces animals to explore lower grazing horizons, whilst lower grazing intensities provide better selection opportunities for animals, resulting in greater intakes. Difante et al. (2009) observed decreased intake (20\%) for 25 $\mathrm{cm}$ in comparison to $50 \mathrm{~cm}$ post-grazing heights in Panicum maximum managed at $95 \%$ LI. The CP content found in pastures in the current study was relatively high, reflecting the plant growth stage and the use of $\mathrm{N}$ fertilizer. Assuming a ruminal degradability of protein of $800 \mathrm{~g} / \mathrm{kgCP}$ (Bowen et al., 2008), it would result in rumen degradable protein (RDP)/digestible organic matter (DOM) ratios of 195 and $197 \mathrm{~g} \mathrm{RDP} / \mathrm{kg}$ DOM for both grazing intensities, values that are in excess of the RDP requirements for microbial protein synthesis in the rumen (CSIRO, 2007). The lower ADG observed in the high grazing pressure is primarily a result of the lower FM allowance used for that pasture management, but could also be linked to harvesting constraints and/or lower availability of leaves in the lower strata, as suggested by the differences found in morphological composition between the post-grazing FM in both treatments. In spite of that, no significant differences were found between treatments in the chemical composition of the grazing horizon samples. However, as stated by Fonseca et al. (2012), the grazing-down process reaching sward heights inferior to $60 \%$ of the initial grazing point would negatively affect the short-term forage intake, leading to lower performance, as observed in animals on more severe grazing treatment. The use of energy supplement at $6 \mathrm{~g} / \mathrm{kg} \mathrm{BW}$ very effectively minimized the deleterious effects on performance, resulting in the second highest ADG for the supplemented animals subjected to high grazing pressure, despite the lower FM allowance.

The FM samples had a high proportion of leaves in all treatments, although they required different grazing intervals. The intervals varied from 10 to 24 days for $15 \mathrm{~cm}$ post-grazing height and from 15 to 31 days for pastures managed at $10 \mathrm{~cm}$ post-grazing height. No differences in forage accumulation can be explained by a compensation in the number of grazing cycles. Therefore, the high stocking rate achieved was due to either a lower intake and/or a more efficient grazing process. Using variable grazing intervals, Euclides et al. (2014) found more leaves in Panicum maximum compared with fixed grazing intervals(553 vs. $483 \mathrm{~g} / \mathrm{kg})$. Higher pasture utilization achieved with higher grazing pressure could negatively affect the production and persistency of the grass in the long term with a nonvariable grazing interval if not enough time was allowed for the plants to recover. However, the adoption of a target pre-grazing height could overcome this problem by allowing time for plants to replenish their reserves, and, as previously stated, sward height of approximately $25 \mathrm{~cm}$ in marandu palisade grass has been positively correlated to $95 \%$ LI (Trindade et al., 2007). In spite of this, to maximize forage intake, it is necessary to remove animals when the sward reaches $60 \%$ of the pre-grazing height (Fonseca et al.,2012). Trindade et 
al. (2007) found a lower proportion of leaves in extrusa samples harvested from esophageal-fistulated animals during the grazing-down process. The $10 \mathrm{~cm}$ post-grazing height treatment most likely did not result in enough allowance of FM to provide better selection opportunities, and therefore resulted in decreases in ADG, despite the minimal differences in FM chemical composition. The $17.4 \%$ decrease in ADG between the two grazing intensity treatments when non-supplemented, demonstrates the impact of forage allowance on animal performance. The use of a citrus pulp-based supplement decreased this deleterious effect.

The pasture stocking rate of nonsupplemented animals was $31 \%$ higher [7.80 vs. 5.95 Animal Units (AU=450 $\mathrm{kg} \mathrm{BW} / \mathrm{ha}$ ]in pastures managed at 10 $\mathrm{cm}$ post-grazing height but beef yield $(8.55 \mathrm{vs}$. $7.35 \mathrm{~kg}$ BW gain $/$ ha/day) was not increased because of lower individual performances. Sarmento (2007) observed a decrease in AD Gof cattle grazing marandu palisade grass with severe grazing, but a much higher stocking rate that resulted in increased beef yield. The supplementation in the present study increased in $82 \%$ the ADG (0.81 vs. $0.445 \mathrm{~kg} \mathrm{BW}$ )resulting in animals $65 \mathrm{~kg}$ heavier than nonsupplemented ones (360 vs. $295 \mathrm{~kg}$ ), regardless of the pasture management strategy. As this supplementation strategy results in heavier cattle, it is

\section{REFERENCES}

AOAC International - Association of Official Analytical Chemists. Official Methods of Analysis. 15th Ed. AOAC Press, Gaithersburg, USA.1990

BOWEN, M.K.;POPPI,D.P.; MCLENNAN, S.R. Ruminal protein most likely that animals will require less days on feed during feedlot phase or will have heavier carcasses at slaughter for specific market demands.

\section{CONCLUSION}

The use of $6 \mathrm{~g} / \mathrm{kg}$ BW supplement was more effective than grazing management to increase beef yield, most likely because of increments of metabolizable energy in the final diet. Growing bulls achieved highest BW gains when supplementation was combined with lower grazing pressure, resulting in positive synergistic effects on animal performance. Despite not reaching as high BW gains, the use of an energy supplement was effective to overcome the negative effects of more severe grazing, increasing individual ADG of growing bulls and resulting in high beef yields despite the grazing strategy adopted.

\section{ACKNOWLEDGEMENTS}

The authors are grateful to Professor Dennis Poppi and Dr. Simon Quigley (SAFS-UQ, Australia) for reviewing the manuscript and providing valuable suggestions, and the São Paulo Research Foundation (FAPESP) for partially funding this research.

degradability of a range of tropical pastures. Australian Journal of Experimental Agriculture, v. 48, p. 806-810,2008.

CSIRO - Commonwealth Scientific and Industrial Research Organization, Nutrient requirements of domesticated 
ruminants. CSIRO Publications:

Collinwood, Victoria, Australia. 2007.

CARNEVALLI, R.A.;DA SILVA, S.C.;BUENO, A.A.O.;UEBELE, M.C.;BUENO, F.O.;HODGSON, J.;SILVA, G.N.;MORAIS,

J.P.G.Herbage production and grazing losses in Panicum maximum cv. Mombaça under four grazing managements. Tropical Grasslands, v. 40, p.165-176,2006.

CONGIO G.F.S.;BATALHA, C.D.A.;CHIAVEGATO, M.B.;BERNDT, A.;OLIVEIRA, P.P.A.;FRIGHETTO,

R.T.S.;MAXWELL,

T.M.R.;GREGORINI, P.;DA SILVA, S.C. Strategic grazing management towards sustainable intensification at tropical pasture-based dairy systems.

Science of The Total Environment, v. 636, p. 872-880, 2018.

\section{DA SILVA, S.C.;GIMENES}

F.M.A.;SARMENTO

D.O.L.;SBRISSIA A.F.;OLIVEIRA

D.E.;HERNANDEZ-GARAY A.; PIRES A.V. Grazing behavior, forage intake and animal performance of beef cattle heifers on marandu palisade grass subjected to intensities of continuous stocking management. Journal of Agricultural Science,v. 151, p. 727739,2013.

DIFANTE, G.S.;EUCLIDES, V.P.B.;NASCIMENTO, D.; Da SILVA S.C.;TORRES,R.A.A.;SARMENTO, D.O.L.Ingestive behavior, forage intake and grazing efficiency of beef cattle steers on Tanzania guinea grass subjected to rotational stocking managements. Revista Brasileira de Zootecnia,v. 38, p. 1001-1008, 2009.
DRESCHER, M.;HEITKONIG, I.M.A.;VAN DEN BRINK P.J.; PRINSH.H.T. Effects of sward structure on herbivore foraging behaviour in a South African savanna: An investigation of the forage maturation hypothesis. Australian Ecology, v. 31, p. 76-87,2006.

EUCLIDES, V.P.B.; MONTAGNER, D.B.; DIFANTE G.D.S.; BARBOSA, R.A.;FERNANDES, W.S.Sward structure and livestock performance in guinea grass cv Tanzania pastures managed by rotational stocking strategies. Scientia Agricola,v. 71, p. 451-457, 2014.

FAGUNDES, J.L.;DA SILVA, S.C.;PEDREIRA, C.G.S.;CARNEVALLI, R.A.;CARVALHO, C.A.B.;SBRISSIA, A.F.;PINTO, L.F.M.Índice de área foliar, interceptação luminosa e acúmulo de forragem em pastagens de Cynodon spp. sob diferentes intensidades de pastejo.Scientia Agricola,v. 56, p. 1141-1150,1999.

FONSECA, L.;MEZZALIRA,J.C.; BREM, C.;FILHO, R.S.A.; GONDA, H.L.;CARVALHO, P.C.F. Management targets for maximizing the short-term forage intake rate of cattle grazing in Sorghum bicolor. Livestock Science, v. 145 , p. 205-211,2012.

GOERING, H.K.;VAN SOEST, P.J. Forage fiber analyses (apparatus, reagents, procedures and some applications). In 'Handbook No. 379.' Agricultural Research Service/United States Department of Agriculture (ARS/USDA). Washington DC, USA, 1970. 
HODGSON, J. Grazing Management: Science into Practice, Longman Scientific and Technical, New York, NY, USA, 1990.

KENWARD M.;ROGER, J. Small sample inference for fixed effects from restricted maximum likelihood.

Biometrics, v. 53, p. 983-997,1997.

NRC - National Research Council Nutrients requirements of beef cattle. 7th Ed. The National Academy of Sciences, Washington DC, USA,2000.

POPPI, D.P.; MCLENNAN, S.R. Protein and energy utilization by ruminants at pasture. Journal of Animal Science, v. 73, p. 278290,1995 .

POPPI, D.P.;MINSON, D.J.;TERNOUTH J.H. Studies of cattle and sheep eating leaf and stem fractions of grasses. 3. The retention time in the rumen of large feed particles.

Australian Journal of Agricultural

Research, v. 32, p. 23-137,1981.

SANTOS, F.A.P.;DOREA, J.R.R.;DE SOUZA, J.;BATISTEL, F.; COSTA, D.F.A.Forage management and methods to improve nutrient intake in grazing cattle. In: 25th Annual Florida ruminant nutrition symposium, Gainesville, Florida, USA. p 144$165,2014$.

SARMENTO, D.O.L.; Forage accumulation, morphological composition and nutritive value in Brachiaria brizantha (Hochst x A. Rich) Stapf. Cv Marandu subjected to rotational stocking strategies with beef cattle. PhD dissertation. University of Sao Paulo, Piracicaba, SP, Brazil.2007,

TRINDADE, J.K.;DA SILVA S.C.;DE SOUZA S.J.Morphological composition of the forage consumed by beef cattle during the grazing down process of marandu palisade grass subjected to rotational strategies. Pesquisa

Agropecuária Brasileira,v. 42, p. 883$890,2007$.

VAN SOEST, P.J.;ROBERTSON, J.B.;LEWIS, B.A.; Methods for dietary fiber, neutral detergent fiber, and nonstarch polysaccharides in relation to animal nutrition. Journal of Dairy Science, v. 74, p. 3583-3597,1991.

WAINMAN, F.W.; DEWEY,J.S. Feedstuffs evaluation unit - fifth report, Bucksburn, Scotland, UK: Rowett Research Institute, p.123 1988. 